|| Print ISSN: 2589-7837 || Online ISSN: 2581-3935 ||

International Journal of Medical Science and Diagnosis Research (IJMSDR)

Available Online at www.ijmsdr.com

NLM (National Library of Medicine ID: 101738824)

Case study

Volume 5, Issue 8; August:2021; Page No. 01-06

\title{
Thrombotic Thrombocytopenic Purpura (TTP)
}

\section{Ashraf ALakkad', Mohamed Gamea ${ }^{2}$, Hesham Hussien ${ }^{3}$, Mahmoud Sami ${ }^{4}$, Salah Eldin Khalii ${ }^{5}$, Adel Ahmed ${ }^{6}$ and Noorullah Mohammed ${ }^{7}$ \\ ${ }^{1}$ Internal Medicine Unit, Madinat Zayed Hospital, United Arab Emirates. \\ ${ }^{2}$ Neurology Unit MZH, United Arab Emirates. \\ ${ }^{3}$ Critical care Unit, MZH, United Arab Emirates. \\ ${ }^{4}$ Critical care Unit, MZH, United Arab Emirates. \\ ${ }^{5}$ Nephrology Unit, MZH, United Arab Emirates. \\ ${ }^{6}$ Nephrology Unit, MZH, United Arab Emirates. \\ ${ }^{7}$ Cardiology Unit, MZH, United Arab Emirates}

\section{Conflicts of Interest: Nil}

Corresponding author: Dr. Ashraf ALakkad

DOI: https://doi.org/10.32553/ijmsdr.v5i8.833

\begin{abstract}
:
Thrombotic thrombocytopenic purpura is a medical emergency with varied clinical manifestations. TTP is a rare condition, but one that carries a high mortality. High index of suspicion with careful evaluation of thrombocytopenia and hemolytic anemia is of paramount importance. Symptoms result from microthrombi affecting microcirculation and can be varied depending on the organs involved. Laboratory parameters of microangiopathic hemolytic anemia i.e. schitocytosis and increased LDH and indirect hyperbilirubinemia support the diagnosis. Plasma exchange is the treatment of choice. Other modalities that may provide therapeutic benefit in cases of relapsing TTP or in patients with slow or partial response to plasma exchange include vincristine and rituximab. Splenectomy done in remission may decrease recurrence in patients with relapsing TTP.
\end{abstract}

\section{Introduction:}

Thrombocytopenic purpura is an uncommon blood disease. It is the condition in which clots are formed in the blood. These clots block the flow of blood into the body. It damages multiple organs in the body such as the heart, kidney and brain due to the Lack of enough oxygen supplies and results in serious problems. Thrombocytopenic purpura use platelets within the blood. The blood clots are formed by the fragments of cells are stick together with the platelets and seal the blood vessels by stopping blood flow. They also break down blood vessels and the number of platelets decreases from the natural level. Symptoms of the TTP include fever, skin patches, anemia, renal dysfunctions, large bruises, breathlessness, misperceptions and headache. (Stanley \& Michalski., 2020)

\section{Literature Review:}

\subsection{History}

It was first identified in 1924 and was labelled as a fatal disease back then too but the cause of it was unknown. It was 1997 when it was discovered that this disease happened due to the deficiency of the ADAMTS13 enzyme.

\subsection{Epidemiology}


Talking about epidemiology as we know that TTP is a very infrequent disease, it usually happens about annually 1 o 13 cases per million people and it quite happens more in women. There is a $90 \%$ chance that it will happen in adults. While in children it happens up to $10 \%$ but the chance is that majority of cases would be genetic, it is not common in pregnant women.

\subsection{Etiology}

The actual cause of this disease is not known yet but it is believed that it happens due to deficiency of an enzyme that is involved in the process of blood clotting, with its deficiency there's not much efficiency in the blood clotting process leading to TTP. (Thrombotic Thrombocytopenic Purpura, 2021)

\subsection{DIAGNOSIS}

TTP should be suspected in patients with thrombocytopenia and Microangiopathic hemolytic anemia (MAHA). It can be diagnosed by acute pancreatitis or bloody diarrhoea and other than that TTP can be diagnosed with visceral organ involvement as we know it is the nervous system that is most commonly affected visceral organ so this disease occurs in this case in like $40 \%$ to $80 \%$ depending upon some symptoms like a minor headache to severe seizures, stroke or even coma. These acute neurological abnormalities like stroke or seizure are involved in preceding MAHA and thrombocytopenia so it can be diagnosed from these symptoms.

Also, blood tests can be done to measure the amount of RBC's or WBC's to know if there is anaemia that may lead to a diagnosis of TTP. (Domingo-González A, 2021)

\section{Case study:}

This study is based on a 43 years old male patient. He was a heavy smoker and alcoholic. Two years before, he was known as a chronic alcohol abuser and he stopped smoking and alcohol consumption.

He was admitted to another facility with an acute confessional state, high-grade fever, dehydration and severe hypotension. He had speech difficulty and generalized weakness. $\mathrm{Ct}$ scan of the brain shows that his brain was normal.

Blood test revealed, he had septicemia. He was treated empirically as sepsis for 5 days. He responded initially for this treatment but on the 5th day of post-admission, he developed some serious problems such as breathing difficulty, fatigue, hypotension and hypoxemia. Then, he was admitted to our hospital for further testing.

Urgent CT scan of the chest: Diagnosed cardiac tamponade from CT scan. Then, he was transferred to our hospital for urgent pericardiocentesis and $350 \mathrm{ml}$ fluid was drained which was hemorrhagic, it was sent for cytology.

Table 1:

\begin{tabular}{|l|l|}
\hline Clinical presentation & Hypotension, Pulses Paradoxes, Tachycardia \\
\hline Precipitating Factors & Alcohol, smoking, cardiac problems, \\
\hline ECG & $\begin{array}{l}\text { Electrical fluctuations (QRS rarely T), Non-specifically change ST-T wave, } \\
\text { agonal phase, }\end{array}$ \\
\hline Chest X-rays & Lungs clear, Cardiac silhouette enlarged, \\
\hline M mode/2D & Diastolic collapse anterior RV free wall, RA collapse, LA and very rarely LV, \\
\hline Echocardiogram & enlarged Wall thickness LV, VCL dilation, 'Swinging heart' \\
\hline $\begin{array}{l}\text { M-mode color } \\
\text { Doppler }\end{array}$ & Breathing fluctuations in tricuspid/ mitral movement \\
\hline
\end{tabular}

Complete blood smear test shows (anaemia, thrombocytopenia, elevated creatinine, total bilirubin and $\mathrm{LDH}$, negative direct Coombs test). All these tests are used to diagnose thrombotic thrombocytopenic purpura (TTP). 
Acute confusion, fever, renal impairment and features of microangiopathic hemolytic anemia with high lactate dehydrogenase (LDH) level and low level of haptoglobin were consistent with a completely different diagnosis: TTP thrombotic microangiopathy.

\section{Laboratory finding:}

Table 2:

\begin{tabular}{|c|c|c|c|}
\hline \multirow{2}{*}{\multicolumn{4}{|c|}{ Lab view }} \\
\hline & & & \\
\hline \multirow{3}{*}{$\begin{array}{l}\text { WBC } \\
\text { RBC } \\
\mathrm{Hgb}\end{array}$} & $12.13 \times 10 \wedge 9 / \mathrm{L}$ & $8.89 \times 10 \wedge 9 / \mathrm{L}$ & $9.71 \times 10 \wedge 9 / \mathrm{L}$ \\
\hline & $1.8 \times 10 \wedge 12$ & $3.13 \times 10 \wedge 12 / \mathrm{L}$ & $*$ (c) $1.88 / \mathrm{L}$ \\
\hline & $66.0 \mathrm{~g} / \mathrm{L}$ & $75.0 \mathrm{~g} / \mathrm{L}$ & $70.0 \mathrm{~g} / \mathrm{L}$ \\
\hline $\begin{array}{l}\text { Hct } \\
\mathrm{MCV}\end{array}$ & $0.212 \mathrm{~L} / \mathrm{L}$ & $0.273 \mathrm{~L} / \mathrm{L}$ & $0.224 \mathrm{~g} / \mathrm{L}$ \\
\hline \multirow{5}{*}{$\begin{array}{l}\text { MCH } \\
\text { MCHC } \\
\text { Platelet } \\
\text { RDW-CV } \\
\text { Reticulocyte }\end{array}$} & $114.6 \mathrm{fL}$ & $111.3 \mathrm{fL}$ & $119.1 \mathrm{fL}$ \\
\hline & $35.7 \mathrm{pg}$ & $35.2 \mathrm{pg}$ & $37.2 \mathrm{pg}$ \\
\hline & $311 \mathrm{~g} / \mathrm{L}$ & $316 \mathrm{~g} / \mathrm{L}$ & $313 \mathrm{~g} / \mathrm{L}$ \\
\hline & $82 \times 10 \wedge 9 / \mathrm{L}$ & $103 \times 10 \wedge 9 / \mathrm{L}$ & $105 \times 10 \wedge 9 / \mathrm{L}$ \\
\hline & $12.4 \%$ & & \\
\hline \multicolumn{4}{|l|}{ Differential } \\
\hline \multirow{2}{*}{$\begin{array}{l}\text { Neutron auto \% } \\
\text { Neutro Auto \# }\end{array}$} & 63.6 & $61.2 \%$ & $71.6 \%$ \\
\hline & $7.72 \times 10 \wedge 9 / \mathrm{L}$ & $5.43 \times 10 \wedge 9 / \mathrm{L}$ & $6.95 \times 10$ \\
\hline
\end{tabular}

ADAMTS Test

ADAMTS 13 ACTIVITY $0.8 \mathrm{IU} / \mathrm{mL}$

Norma low 0.4 Normal High 1.3

Table 3:

\begin{tabular}{|l|l|l|}
\hline Event & Results & Ref . Range \\
\hline TSH & $7.720 \mathrm{milli}$ IU/L & $0.270-4.200$ \\
\hline Free T3 & $2.39 \mathrm{pmol} / \mathrm{L}$ & $3.10-6.80$ \\
\hline Glucose (POC) & $6.8 \mathrm{mmol} / \mathrm{L}$ & \\
\hline Sodium level & $146.0 \mathrm{mmol} / \mathrm{L}$ & $135-145$ \\
\hline Potassium level & $4.3 \mathrm{mmol} / \mathrm{L}$ & $3.6-5.1$ \\
\hline Chloride level & $106.0 \mathrm{mmol} / \mathrm{L}$ & $98-107$ \\
\hline Co2 & $22.2 \mathrm{mmol} / \mathrm{L}$ & $22-29$ \\
\hline Creatinine level & $207.0 \mathrm{Micromol} / \mathrm{l}$ & $62-106$ \\
\hline Urea & $15.70 \mathrm{mmol} / \mathrm{L}$ & 0.008 .3 \\
\hline Bilirubin Total & $648.9 \mathrm{micromol} / \mathrm{L}$ & $-<=21.0$ \\
\hline LDH Lvl & $879 \mathrm{IU} / \mathrm{L}$ & $140-280 \mathrm{U} / \mathrm{L}$ \\
\hline Bilirubin Direct & $673.6 \mathrm{micromol} / \mathrm{L}$ & $-<=5.4$ \\
\hline WBC & $9.71 \mathrm{x} 10 \wedge 9 / \mathrm{L}$ & $4.00-11.00$ \\
\hline
\end{tabular}

Table 4:

\begin{tabular}{|l|l|l|l|}
\hline Phosphate level & & $0.42 \mathrm{mmol} / \mathrm{L}$ & $0.44 \mathrm{mmol} / \mathrm{L}$ \\
\cline { 2 - 4 } LDH level & $879 \mathrm{IU} / \mathrm{L}$ & & \\
\hline
\end{tabular}

Lactate dehydrogenase (LDH) Test greater than normal range. 
Normal $=100-190 \mathrm{U} / \mathrm{L}$

\section{Haptoglobin level test}

Haptoglobin Test $<0.10 \mathrm{~g} / \mathrm{L}$ (LOW)

Normal Low 0.30 Normal high 2.00

\section{Electrolyte panel:}

Table 5:

\begin{tabular}{|c|c|c|c|}
\hline \multicolumn{4}{|l|}{ General chemistry } \\
\hline \multirow{6}{*}{$\begin{array}{l}\text { Sodium level } \\
\text { Possum level } \\
\text { Chloride level } \\
\text { Co2 } \\
\text { Creatinine level } \\
\text { Urea level }\end{array}$} & $145.0 \mathrm{mmol} / \mathrm{L}$ & $146.0 \mathrm{mmol} / \mathrm{L}$ & $146.0 \mathrm{mmol} / \mathrm{L}$ \\
\hline & $4.2 .0 \mathrm{mmol} / \mathrm{L}$ & $3.4 \mathrm{mmol} / \mathrm{L}$ & $3.6 \mathrm{mmol} / \mathrm{L}$ \\
\hline & $107.0 \mathrm{mmol} / \mathrm{L}$ & $108.0 \mathrm{mmol} / \mathrm{L}$ & $109.0 \mathrm{mmol} / \mathrm{L}$ \\
\hline & $13.0 \mathrm{mmol} / \mathrm{L}$ & $19.8 \mathrm{mmol} / \mathrm{L}$ & 18.0 mmol/L \\
\hline & $333.0 \mathrm{mmol} / \mathrm{L}$ & 302.0 micromitre & $221.0 \mathrm{mmol} / \mathrm{L}$ \\
\hline & $29.80 \mathrm{mmol} / \mathrm{L}$ & $25.00 \mathrm{mmol} / \mathrm{L}$ & $18.20 \mathrm{mmol} / \mathrm{L}$ \\
\hline
\end{tabular}

Table 6:

\begin{tabular}{|l|l|l|}
\hline ALT & $27.6 \mathrm{IU} / \mathrm{L}$ & $(0.00-41)$ \\
\hline WBC & $12.90 \times 10^{\wedge} 9 / \mathrm{L}$ & $(4.0-11.00)$ \\
\hline RBC & $2.21 \times 10^{\wedge} 12 / \mathrm{L}$ & $(4.50-6.50)$ \\
\hline $\mathrm{Hgb}$ & $74.0 \mathrm{~g} / \mathrm{L}$ & $(130.0-180.0)$ \\
\hline $\mathrm{HCt}$ & $0.236 \mathrm{~L} / \mathrm{L}$ & $(0.400-0.540)$ \\
\hline $\mathrm{MCV}$ & $106.8 \mathrm{fL}$ & $(76.0-96.0)$ \\
\hline
\end{tabular}

\section{CRRT and TPE}

The patient was intubated and we started Continues renal replacement therapy (CRRT) without anticoagulation for refractory acidosis and a rising creatinine.

He received daily 5 sessions of TPE therapeutic plasma exchange with FFP replacement

He was started on Methylprednisolone $10 \mathrm{mg} / \mathrm{kg} /$ day then Prednisolone $1 \mathrm{mg} / \mathrm{kg} /$ day.

His Kidney function had improved from these medicines and he started to pass urine about 800 $\mathrm{ml} / 24$ hour. His Cardiac performance was also better and no more pericardiac collection were detected.

His number of platelets were improved and bilirubin level was decreased with nearly normal liver enzymes.
We removed his tube and PermCath. Now he was fully conscious and oriented. Initially, $\mathrm{He}$ was weak and unable to walk but later he had dramatic improvement and started walking.

For the treatment of hypothyroidism, we recommended synthetic thyroid hormone levothyroxine Synthroid, Levo-T. These medicines are consumed orally. Daily use helps to control hormonal levels in the body and restores thyroid hormone.

He was discharged from our hospital in a stable condition with home medications.

His discharge medication were:

1. Ferrous sulfate-foLIC acid: 1 cap, PO, Lunch PC

2. HydroCORTISone: $10 \mathrm{mg}, 1 \mathrm{tab}, \mathrm{PO}, \mathrm{BID}$

3. levoTHYROxine: $150 \mathrm{mcg}$, PO, Bedtime

4. multivitamin: 1 tab, PO, BID

5. omeprazole: $40 \mathrm{mg}, 2 \mathrm{tab}$, PO, Daily AC 
Serum Electrolyte profile test on discharge:

Table 7:

\begin{tabular}{|l|l|l|}
\hline Event & Result & Ref. Range \\
\hline Creatinine & $134.0 \mathrm{micromol} / \mathrm{L}$ & $(62.0-106.0)$ \\
\hline Urea Lvl & $19.90 \mathrm{mmol} / \mathrm{L}$ & $(0.00-8.30)$ \\
\hline Calcium Lvl & $2.430 \mathrm{mmol} / \mathrm{L}$ & $(2.100-2.600)$ \\
\hline Calcium Corr & $2.36 \mathrm{mmol} / \mathrm{L}$ & $(2.10-2.60)$ \\
\hline Albumin Lvl & $43.3 \mathrm{~g} / \mathrm{L}$ & $(35.0-50.0)$ \\
\hline ASt & $27.5 \mathrm{IU} / \mathrm{L}$ & $(0.0-38.0)$ \\
\hline Alt & $26.7 \mathrm{IU} / \mathrm{L}$ & $(0.0-41.0)$ \\
\hline Phosphate Lvl & $1.30 \mathrm{mmol} / \mathrm{L}$ & $(0.87-1.45)$ \\
\hline
\end{tabular}

\section{Discussion}

This disease is said to be very rare but its rarity does mean that this is a fatal disease, if not treated it can get one's life. The cause of this disease was totally unknown before but now it is said that it happens when there is less amount of the enzyme ADAMTS13 which is basically enzyme of a gene that controls the process of blood clotting so a deficiency of this enzyme would mean that the process of blood clotting is not efficient. TTP can actually affect any organ system be it kidneys or the central nervous system.

MAHA which is basically a feature of TTP that is hemolytic anaemia that is characterized by schistocytes that are usually found in healthy people, these schistocytes may happen due to red blood cell defects that may lead to problems in clotting hence causing the TTP. (Patol., 2018)

\section{Summary}

It is summarized that TTP is a very deadly disease that happens in people that have quite large multimers of vWF leading to deficiency of ADAMTS13 that helps in blood clotting and it can be diagnosed by various processes like blood test measures, platelet counts and coagulation studies. (Sukumar S, 2021)

\section{Conclusion}

This study shows that TTP is a very dangerous but still treatable disease because there are ways to cure this disease such as corticosteroids, some anti-platelets agents such as aspirin and other ways like plasma infusion or plasma exchange.

TTP has been evolved from a disease that was once universally fatal to now an illness that if diagnosed early has a remission rate exceeding $90 \%$. Because there has been a lot of success in the treatment of TTP with the infusion of plasma and its exchange this disease is now totally curable.

\section{Reference}

1. Domingo-González A, Regalado-Artamendi I, Martín-Rojas RM, Pérez-Rus G, PérezCorral A, Díez- Martín JL, Pascual C. Application of the French TMA Reference Center Score and the mortality in TTP Score in de novo and relapsed episodes of acquired thrombotic thrombocytopenic purpura at a tertiary care facility in Spain. Journal of Clinical Apheresis. 2021 Feb 3.

2. Patol., J. B. (2018, August). Thrombotic thrombocytopenic purpura: a case report. Retrieved from Scielo Brazil: https://www.scielo.br/j/jbpml/a/XV8cHXT4 tWkvZNPsVm9k9xw/?lang=en

3. Stanley, M., \& Michalski., J. M. (2020, 16 August). Thrombotic Thrombocytopenic 
Purpura. Retrieved from NCBI: https://www.ncbi.nlm.nih.gov/books/NBK4 30721/

4. Thrombotic Thrombocytopenic Purpura. (2021). Retrieved from National Organzation of Rare Disease: https://rarediseases.org/rare-diseases/ thrombotic-thrombocytopenic-purpura/

5. Sukumar S, Lämmle B, Cataland SR. Thrombotic thrombocytopenic purpura: Pathophysiology, diagnosis, and management. Journal of Clinical Medicine. $2021 \mathrm{Jan} ; 10(3): 536$. 